\title{
Performance evaluation of mechanized manufacture of bottle gourd Halwa
}

\section{C.S. Baladhiya, J.S. Doshi and V.B. Bhalodiya}

See end of the Paper for authors' affiliation

Correspondence to :

C.S. Baladhiya Department of Agricultural Engineering, B.A. College of Agriculture, Anand Agricultural University, Anand (Gujarat) India Email: csbaladhiya@gmail.com
-ABSTRACT : India has world's largest production of milk and 50-55 per cent of its production being used for the manufacture of different Traditional Indian Dairy Products (TIDP). The manufacture of traditional dairy products on large scale requires mechanization and optimization of operating conditions in order to get uniform acceptable quality. Scraped Surface Heat Exchanger (SSHE) of appropriate design is found suitable for production of highly viscous dairy products. Bottle gourd Halwa is one of the Traditional Indian Dairy Products (TIDP) prepared from grated bottle gourd cooked with Ghee, sugar, Khoa, and flavoured by spices like cardamom. The various unit operations involved in preparation of bottle gourd Halwa are shredding, cooking and desiccation with sugar and Khoa. The study was taken to evaluate heat transfer performance of the SSHE during manufacture of bottle gourd Halwa under variable operating conditions. The horizontal SSHE was used for the manufacturing of Halwa using the recipe standardized by Response Surface Methodology. The performance of the SSHE was evaluated at different scraper speeds and operating steam pressures. The rate of evaporation ranged between 12.379 and 19.947 $\mathrm{kg}$ water/h during manufacturing of Halwa in SSHE at different operating conditions. It was observed that overall heat transfer co-efficients (U-values) increased with the increase in scraper speed and steam pressure in range of $406-600 \mathrm{~W} / \mathrm{m}^{2} \mathrm{~K}$. The values of steam consumption and electrical power consumption under different operating conditions during manufacture of bottle gourd Halwa ranged from 18.56 to $36.76 \mathrm{~kg} / \mathrm{h}$ and 0.398 to $0.410 \mathrm{kWh}$, respectively. The values of specific steam consumption ranged from 1.659 to $1.697 \mathrm{~kg}$ steam $/ \mathrm{kg}$ water evaporated. The total heat losses during manufacture of Halwa in the SSHE ranged from 20.84 to 23.83 per cent of the heat input at different steam pressures and scraper speeds.

- KEY WORDS : Bottle gourd Halwa, Scraped surface heat exchanger, Energy analysis, Sensible heat

-HOW TO CITE THIS PAPER : Baladhiya, C.S., Doshi, J.S. and Bhalodiya, V. B. (2020). Performance evaluation of mechanized manufacture of bottle gourd Halwa. Internat. J. Agric. Engg., 13(1) : 113-120, DOI: 10.15740/HAS/IJAE/13.1/113-120. Copyright@2020: Hind Agri-Horticultural Society. 